\title{
Theoretical Studies on the Hydride Ion Affinities of Carbocations
}

\author{
Chang Kon Kim, Kyung A Lee, Soo Youn Bae, In Suk Han, and Chan Kyung Kim* \\ Department of Chemistry, Inha Lniversitv, Inchon 402-751, Norea \\ Received September 30, 2003
}

Key Words : Hydride ion affinity. Carbocations. G2 Calculation G3 Calculations

Carbocations are key intermediates in many organic reactions. and hence reaction mechanisms as well as reaction rates involving carbocation intermediates could be affected by their stabilities. Relative stabilities and factors influencing the stabilities of carbocations in solution have been well demonstrated and one of important trends to stabilize them is to add additional alkyl groups. ${ }^{\text {l Nevertheless. the }}$ intrinsic stabilities of carbocations should be determined in the gas phase rather than in solution. because the relative stabilities of carbocations in solutions might be strongly influenced by the solvent effects due to their characteristic positive charge. For example. ionization of tert-butyl chloride. $\left(\mathrm{CH}_{3}\right)_{3} \mathrm{CCl} \rightarrow\left(\mathrm{CH}_{3}\right)_{3} \mathrm{C}^{+}+\mathrm{Cl}^{-}$, is highly endothermic by 153 $\mathrm{kcal} \mathrm{mol}^{-1}$ in the gas phase indicating unobservably slow reaction. ${ }^{2}$ Whereas it has been well known that the ionization of tert-butyl chloride is feasible in solutions because of the solvation of the ions. Moreover the difference in stabilities between tertiary and secondary alky̆l cations is about $17 \mathrm{kcal}$ $\mathrm{mol}^{-1}$ in the gas phase but only about $9.5 \mathrm{kcal} \mathrm{mol}^{-1}$ in the $\mathrm{SO}_{2} \mathrm{ClF}$ solution. ${ }^{3}$ However. unfortunately. quantitative data for the stabilities of carbocations in the gas phase are very limited albeit some have been reported for simple carbocations.

One approach determining the intrinsic stabilities of carbocations in the gas-phase is theoretical measurement of the hydride ion affinity (HIA) of a carbocation. defined as a negative value of the reaction enthalpy in eq. (1) (HIA = $\left.-\Delta H^{9}\right)^{+}$However. with our knowledge it is difficult to obtain accurate energy of hỵdride ion using the theoretical approach. because the calculated electronic energies are strongly dependent on the basis sets and theoretical levels employed. Therefore selecting an appropriate basis set as well as a theoretical level is an important process in the calculations of the HIA of carbocations. In this work. various theoretical levels combined with several basis sets are examined to determine the gas-phase HIA of carbocations.

$$
\mathrm{R}^{-}+\mathrm{H}^{-} \rightarrow \mathrm{R} \cdot \mathrm{H}
$$

\section{Calculation}

All the stationary species in eq. (1) were fully optimized at $\mathrm{HF}$ and $\mathrm{MP} 2(\mathrm{FC})$ levels with various basis sets. i.e. two

\footnotetext{
Corresponding Author. Fax: +82-32-867-5604: e-mail: kekyung âinha.ac.kr
}

standard Pople type basis sets. ${ }^{5}$ 6-311++G(d.p) and 6$311++\mathrm{G}(3 \mathrm{df} .2 \mathrm{p})$, and one triple-zeta basis set with diffuse function of the Dunning s correlation consistent basis set. Aug-cc-pVTZ. ${ }^{6}$ The gas-phase optimized species were characterized by their vibrational frequencies at the RHF/6$311++\mathrm{G}\left(\mathrm{d}\right.$.p) level using the Gaussian 98 program package. ${ }^{7}$ Calculated energies were further refined by the modified G2. ${ }^{8}$ (MP2). ${ }^{9} 3^{10}$ and G3(MP2) ${ }^{11}$ methods using the optimized geometries at the MP2(FC)/6-311++G(3df.2p) level and thermochemical data at the HF/6-311+G(d,p) level. Also the calculated energies at the G2 and G3 levels were compared with those at QCISD(T) level using the optimized geometries at the MP2(FC) level with corresponding basis set.

\section{Results and Discussion}

To test the effects of theoretical levels and basis sets on the accuracy for the calculated HIA values. the heterolytic bond dissociation enthalpy of hydrogen molecule. eq. $2,{ }^{12}$ is calculated by using various theoretical levels and basis sets. The calculated enthalpies $(\mathrm{H})$. heats of formation $\left(\Delta \mathrm{H}_{\mathrm{f}}\right)$ and heterolytic bond dissociation enthalpies $\left(\Delta \mathrm{H}_{\mathrm{D}}\right)$ at $298 \mathrm{~K}$ are collected in Table 1. Examination of Table 1 shows that the calculated $\Delta \mathrm{H}_{\mathrm{f}}$ values of hydrogen molecule are more accurate for higher theoretical levels. as is generally

$$
H_{i q q !} \rightarrow H_{i q !}^{-}+H_{(\xi)}^{-}
$$

expected. For example. the $\Delta \mathrm{H}_{\mathrm{f}}$ values at the QCISD(T) levels are excellently agreed with the definitive value $\left(\Delta \mathrm{H}_{\mathrm{f}}=\right.$ $0.0 \mathrm{kcal} \mathrm{mol}^{-1}$ ) within about $2 \mathrm{kcal} \mathrm{mol}^{-1}$, but those at the relatively low correlated MP2 and uncorrelated RHF levels are much larger by $5-28 \mathrm{kcal} \mathrm{mol}^{-1}$.

On the contrary, the calculated $\Delta \mathrm{H}_{\mathrm{D}}$ values are well agreed with the experimental value ${ }^{13}$ of $400.4 \mathrm{kcal} \mathrm{mol}^{-1}$ within about $\pm 4 \mathrm{kcal} \mathrm{mol}^{-1}$ in all theoretical levels except for the $\mathrm{G} 2$ and $\mathrm{G} 3$ levels, i.e. the $\Delta \mathrm{H}_{\mathrm{D}}$ values are as accurate as those at the QCISD(T) levels even at the uncorrelated RHF and low correlated MP2 levels. albeit larger errors found at the RHF and MP2 levels. However. close examination of Table 1 shows that the accuracy found at the RHF and MP2 levels is only fortuitous. This results from the cancellation of errors found in the enthalpies of both $\mathrm{H}_{2}$ and $\mathrm{H}^{-}$species. Therefore, although the $\Delta \mathrm{H}_{\mathrm{D}}$ values of $\mathrm{H}_{2}$ molecule at the RHF and MP2 levels are accurate. it could be expected that both theoretical levels are. in general. inadequate for 
Table 1. The calculated heat of fomation $\left(\Delta \mathrm{H}_{\mathrm{f}}\right)$ and heterolytic bond dissociation enthalpy $\left(\Delta \mathrm{H}_{\square}\right)$ of hydrogen molecule, eq. (2), at $298 \mathrm{~K}$

\begin{tabular}{|c|c|c|c|c|c|}
\hline Method & Basis set & Enthalpy $\left(\mathrm{H}^{-}\right)^{a}$ & Enthalpy $\left(\mathrm{H}_{2}\right)^{a}$ & $\Delta \mathrm{H}_{\mathrm{f}}\left(\mathrm{H}_{2}\right)^{b}$ & $\Delta \mathrm{H}_{\mathrm{I}}{ }^{b . c}$ \\
\hline \multirow{5}{*}{$\mathrm{HF}$} & $6-311++G(d, p)$ & -0.48460 & -1.11873 & 25.9 & 399.4 \\
\hline & $6-311++G(3 \mathrm{dt}, 2 \mathrm{p})$ & -0.48460 & -1.11926 & 25.6 & 399.7 \\
\hline & Aug-cc-pVDZ & -0.48442 & -1.11514 & 27.6 & 397.3 \\
\hline & Aug-cc-pVTZ & -0.48528 & -1.11930 & 25.6 & 399.3 \\
\hline & Aug-cc-pVQZ & -0.48545 & -1.11977 & 25.4 & 399.5 \\
\hline \multirow{5}{*}{ MP2 } & $6-311+\mathrm{G}(\mathrm{d}, \mathrm{p})$ & -0.50325 & -1.14667 & 8.4 & 405.2 \\
\hline & $6-311+\mathrm{G}(3 \mathrm{df}, 2 \mathrm{p})$ & -0.50722 & -1.14918 & 6.8 & 404.3 \\
\hline & Aug-cc-pVDZ & -0.50460 & -1.14275 & 10.2 & 398.8 \\
\hline & Aug-cc-pVTZ & -0.51355 & -1.15143 & 5.4 & 401.8 \\
\hline & Aug-cc-pVQZ & -0.51473 & -1.15315 & 4.5 & 402.1 \\
\hline $\mathrm{G} 2$ & - & -0.49609 & -1.16205 & -1.3 & 419.6 \\
\hline $\mathrm{G} 2(\mathrm{MP} 2)$ & - & -0.49609 & -1.16205 & -1.0 & 419.4 \\
\hline $\mathrm{G3}$ & - & -0.51636 & -1.16348 & -0.7 & 407.6 \\
\hline $\mathrm{G} 3(\mathrm{MP} 2)$ & - & -0.51904 & -1.16626 & -1.4 & 407.6 \\
\hline \multirow{6}{*}{ QCISD $(T)$} & $6-311++G(d, p)$ & -0.51251 & -1.15500 & 1.9 & $4(04.6$ \\
\hline & $6-311++G(3 \mathrm{de}, 2 \mathrm{p})$ & -0.51737 & -1.15751 & 0.3 & 403.2 \\
\hline & Aug-cc-pVDZ & -0.52167 & -1.15170 & 4.6 & 3968 \\
\hline & Aug-cc-pVTZ & -0.52420 & -1.15930 & 0.5 & 4000 \\
\hline & Aug-cc-p VQZ & -0.52478 & -1.16054 & -0.2 & 400.4 \\
\hline & & $-0.52630^{\circ}$ & & 0.0 & 400.4 \\
\hline
\end{tabular}

"In hartree. "In kcal mol ". "In eq. (2), the calculated enthalpy of proton was obtained by a translation enthalpy and a $\Delta(\mathrm{PV})$ term which sum to $1.5 \mathrm{kcal}$ $\mathrm{mol}^{-1}$. Wiberg. K. B. J. Ong. Chem. 2002. 67, 4787. 'Experimental value is estimated from the experimental ionization energy and electron affinity of hydrogen atom.

calculations of HIA of carbocations. Instead. the calculated $\Delta \mathrm{H}_{\mathrm{D}}$ values at the QCISD(T) levels with the Dunning 's basis sets beyond triple zeta or the Pople type $6-311+\mathrm{G}(3 \mathrm{df} .2 \mathrm{p})$ basis set are excellently agreed with the experiniental values for both $\Delta \mathrm{H}_{\mathrm{t}}\left(\mathrm{H}_{2}\right)$ and $\Delta \mathrm{H}_{\nu}$. Therefore we have to employ some computationally expensive methods to predict the experimental HIA values. Unfortunately, such higher level calculations night be too expensive even for the species with moderate sizes in practical purposes due to the limits in the coniputer resource.

On the other hand. the errors in the $\Delta H_{\nu}$ values at the $G 2$ and $\mathrm{G} 3$ levels (including the G2(MP2) and $\mathrm{G} 3(\mathrm{MP} 2$ ) levels) are $3.2-15.2 \mathrm{kcal} \mathrm{mol}^{-1}$. when compared to the experimental value. Thus the $\mathrm{G} 2$ and $\mathrm{G} 3$-type methods are also inadequate for the calculations on the HIAs of carbocations. even though these methods are known to give highly reliable results for most chemical reactions. Close inspection of Table 1 shows that the calculated $\Delta \mathrm{H}_{\mathrm{t}}$ of the hydrogen molecule at the G2 and G3 levels (including G2(MP2) and G3(MP2) levels) are relatively well consistent with the definitive values within $1.4 \mathrm{kcal} \mathrm{mol}^{-1}$. Therefore relatively large deviations in the $\Delta \mathrm{H}_{\mathcal{L}}$ values at these levels of theory should be originated from the inadequate considerations for the hydride ion. Indeed. the calculated enthalpies of hydride ion are largely underestimated compared to the experimental value of -0.52630 Hartree estimated from the experimental ionization energy and electron affinity ${ }^{13}$ of hydrogen atom (Table 1). Therefore the $\Delta \mathrm{H}_{\mathrm{L}}$ values calculated at the $\mathrm{G} 2$ and G3 levels might be improved through some appropriate correction on the enthalpy of the hydride ion (vide infra).
The calculated HIA values $\left(-\Delta \mathrm{H}^{\mathrm{j}}\right)$ at $298 \mathrm{~K}$ for several simple liydrocarbons are collected in Table 2 . As is expected from the above results. the calculated HIA values at the uncorrelated RHF and the low correlated MP2 levels are largely deviated from the experimental values, although the calculated $\Delta \mathrm{H}_{\nu}$ values of hydrogen molecule at both the RHF and MP2 levels are well agreed with the experimental value. Similarly, the calculated HIA values even at the G2 and G3 levels are also largely deviated from the experimental values. Of course, the calculated HIA values at the QCISD(T) level with the Dunning's Aug-cc-pVTZ or the Pople type 6-311++G(3df.2p) basis set are well consistent with the experimental values. Nonetheless. as noted in above the calculations at the QCISD(T) levels using either basis set is not possible even for the allyl or t-butyl system. ${ }^{15}$

Alternative to the QCISD(T) level calculation is to perform the calculation at the HF. MP2. G2 and G3 levels including the G2(MP2) and G3(MP2) levels and to use experimental enthalpy of hydride ion. For example, the calculate HIA values at the $\mathrm{G} 2$ level are largely deviated by $17.2-22.4 \mathrm{kcal} \mathrm{mol}^{-1}$. when theoretically obtained enthalpies are used for all species. However. the HIA values at the $\mathrm{G} 2$ level are as comparable as the QCISD(T)/6-311++G(3df.2p)// $\mathrm{MP} 2 / 6-311++\mathrm{G}(3 \mathrm{df}, 2 \mathrm{p})$ results by only using the experimental enthalpy of hydride ion (Table 2). The errors in the HIA values at the HF and MP2 obtained from this strategy do not improve except for the largest basis set at MP2. which is not practical for usual computations. Therefore this correction could be the most practical and efficient methods to obtain theoretically accurate HIA values at the G2 or G3 
Table 2. The differences between the calculated and experimental $\mathrm{HLA}$ values $\left(-\delta \Delta \mathrm{H}^{\circ} \mathrm{j}^{\mathrm{a}}\right.$ at $298 \mathrm{~K}$ for simple hydrocarbons

\begin{tabular}{|c|c|c|c|c|c|c|c|}
\hline Method & Basis set & Methyl & Vinyl & Ethỵl & Allyl & iso-Propyl & $t$-Butyl \\
\hline \multirow{3}{*}{$\mathrm{HF}$} & $6-311++G(d, p)$ & $\begin{array}{c}-20.4 \\
(-46.6)\end{array}$ & $\begin{array}{c}-6.6 \\
(-32.8)\end{array}$ & $\begin{array}{c}-8.6 \\
(-34.8)\end{array}$ & $\begin{array}{c}-13.1 \\
(-39.3)\end{array}$ & $\begin{array}{c}-10.1 \\
(-36.6)\end{array}$ & $\begin{array}{c}-12.9 \\
(-39.1)\end{array}$ \\
\hline & $6-311+G(3 \mathrm{df}, 2 \mathrm{p})$ & $\begin{array}{l}-20.2 \\
(-46.4)\end{array}$ & $\begin{array}{c}-6.9 \\
(-33.1)\end{array}$ & $\begin{array}{c}-9.1 \\
(-35.3)\end{array}$ & $\begin{array}{l}-13.5 \\
(-39.7)\end{array}$ & $\begin{array}{l}-10.7 \\
(-36.9)\end{array}$ & $\begin{array}{l}-13.6 \\
(-39.8)\end{array}$ \\
\hline & Aug-cc-pVTZ & $\begin{array}{c}-20.6 \\
(-46.3)\end{array}$ & $\begin{array}{c}-7.5 \\
(-33.2)\end{array}$ & $\begin{array}{c}-9.6 \\
(-35.3)\end{array}$ & $\begin{array}{l}-14.0 \\
(-39.7)\end{array}$ & $\begin{array}{c}-10.2 \\
(-35.9)\end{array}$ & $\begin{array}{c}-14.2 \\
(-39.9)\end{array}$ \\
\hline \multirow{3}{*}{ MP2 } & $6-311+G(\mathrm{~d}, \mathrm{p})$ & $\begin{array}{c}4.1 \\
(-10.4)\end{array}$ & $\begin{array}{l}11.7 \\
(-2.8)\end{array}$ & $\begin{array}{c}4.8 \\
(-9.7)\end{array}$ & $\begin{array}{c}6.5 \\
(-8.0)\end{array}$ & $\begin{array}{c}9.3 \\
(-5.2)\end{array}$ & $\begin{array}{c}7.8 \\
(-6.7)\end{array}$ \\
\hline & $6-311++G(3 d f, 2 p)$ & $\begin{array}{c}6.3 \\
(-5.7)\end{array}$ & $\begin{array}{l}13.0 \\
(-1.0)\end{array}$ & $\begin{array}{c}5.0 \\
(-7.0)\end{array}$ & $\begin{array}{c}7.8 \\
(-4.2)\end{array}$ & $\begin{array}{c}9.3 \\
(-2.7)\end{array}$ & $\begin{array}{c}7.4 \\
(-1.6)\end{array}$ \\
\hline & Aug-cc-pVTZ & $\begin{array}{c}4.2 \\
(-3.8)\end{array}$ & $\begin{array}{c}10.9 \\
(-2.9)\end{array}$ & $\begin{array}{c}3.1 \\
(-1.9)\end{array}$ & $\begin{array}{c}5.9 \\
(-2.1)\end{array}$ & $\begin{array}{c}7.4 \\
(-0.6)\end{array}$ & $\begin{array}{c}5.5 \\
(-2.5)\end{array}$ \\
\hline $\mathrm{G} 2^{b}$ & - & $\begin{array}{l}17.6 \\
(-1.3)\end{array}$ & $\begin{array}{l}22.4 \\
(3.4)\end{array}$ & $\begin{array}{c}17.2 \\
(-1.8)\end{array}$ & $\begin{array}{l}19.5 \\
(0.5)\end{array}$ & $\begin{array}{l}20.4 \\
(1.5)\end{array}$ & $\begin{array}{c}18.4 \\
(-0.5)\end{array}$ \\
\hline $\mathrm{G} 2(\mathrm{MP} 2)^{b}$ & - & $\begin{array}{l}17.3 \\
(-1.7)\end{array}$ & $\begin{array}{l}22.4 \\
(3.5)\end{array}$ & $\begin{array}{c}17.1 \\
(-1.9)\end{array}$ & $\begin{array}{l}19.4 \\
(0.5)\end{array}$ & $\begin{array}{l}20.5 \\
(1.6)\end{array}$ & $\begin{array}{c}18.6 \\
(-0.4)\end{array}$ \\
\hline $\mathrm{G} 3^{b}$ & - & $\begin{array}{c}4.9 \\
(-1.4)\end{array}$ & $\begin{array}{l}10.8 \\
(4.6)\end{array}$ & $\begin{array}{c}6.1 \\
(-0.1)\end{array}$ & $\begin{array}{c}8.1 \\
(1.8)\end{array}$ & $\begin{array}{c}8.8 \\
(2.6)\end{array}$ & $\begin{array}{c}6.6 \\
(0.4)\end{array}$ \\
\hline $\mathrm{G} 3(\mathrm{MP} 2)^{b}$ & - & $\begin{array}{c}4.5 \\
(-0.1)\end{array}$ & $\begin{array}{l}10.1 \\
(5.5)\end{array}$ & $\begin{array}{c}4.9 \\
(0.4)\end{array}$ & $\begin{array}{c}7.4 \\
(2.8)\end{array}$ & $\begin{array}{r}7.8 \\
(3.2)\end{array}$ & $\begin{array}{c}5.7 \\
(1.2)\end{array}$ \\
\hline \multirow{3}{*}{ QCISD(T) } & $6-311+\mathrm{G}(\mathrm{d}, p)$ & -0.6 & 5.2 & 1.2 & 2.3 & 49 & 3.2 \\
\hline & $6-311++G(3 \mathrm{df}, 2 p)$ & 1.2 & 60 & 1.0 & 30 & 4.2 & - \\
\hline & Aug-ce-pVTZ & -1.4 & 3.3 & -1.5 & - & - & - \\
\hline & $\operatorname{Exp}^{c}$ & 313.4 & 288.0 & 270.7 & 255.6 & 249.7 & 236.9 \\
\hline
\end{tabular}

$"$ " $\delta \Delta H^{v}=\left[-\Delta H^{\vee}(\right.$ Cald $\left.)\right]-\left[-\Delta H^{\vee}(\right.$ Exp) $]$ for eq. (1). Parentheses falues are the corrected falues by using the experimental enthalpy of hydride ion instead of the calculated value. 'Experimental falues are obtained from the National Institute of Standard Technology (NIST) database. hittp: whebbook.nist.gof: chemistry

levels without using very expensive QCISD(T) level

Acknowledgement. This work was supported by Korea Research Foundation Grant (KRF-2002-070-C00061)

\section{References}

1. March. J. Adtanced Organic Chemistry. $3^{\text {nd }}$ Ed.: John Wiley \& Sons: New York. 1985: Chapter 5.

2. Berman. D. W.: Anicich. V: Beauchamp. J. L. J. Ant Chem. Soc. 1979. 101. 1239

3. Amett. E. M: Pienta. N. J. J. Am Chent Soc. 1980. 102. 3329

4. Carey, F. A.: Sundberg. R. I. Atranced Organic Chemishy. Part A. $3^{\text {rd }}$ Ed.: Plentum Press: New York. 1990; p 273.

5. (a) McLean. A. D.: Chandler. G. S. J. Chem. Phys. 1980. 72. 5639. (b) Krishnan. R.: Binkley. J. S.: Seeger. R.: Pople. J. A. J. Chem. Plovs. 1980. 72,650.

6. Kendall, R. A.: Dunning. Ir T. H.; Harrison. R. J. J. Chem. Phns. $1994,96,6796$

7. Frisch. M. I.: Trucks, G. W.: Schlegel. H. B.: Scuseria, G. E.: Robb. M. A.: Cheeseman. J. R.: Zakrzewski. V. G.: Montgomery. J. A.. Jr.: Stratmann. R. E.: Burant. J. C.: Dapprich. S.: Millam. J. M.: Daniels. A. D: Kudin. K. N.: Strain. M. C.: Farkas. O.: Tomasi, J.: Barone, V: Cossi, M.: Cammi. R: Memnleci. B: Pomelli. C. Adamo, C.: Clittord, S.: Oelterski. J.: Petersson, G. A.: Avala. P. Y: Cui, Q.: Morokuma, K: Malick, D. K.: Rabuck:
A. D.: Raghavachari. K.: Foresman. J. B.: Cioslowski. T.: Ottiz. J. V: Stetanov. B. B.: Liu. G.: Liashertko. A.: Piskorz. P.: Komaromi. 1: Gomperts. R; Martin. R. L.: Fox, D. J; Keith, T: Al-Laham. M. A.; Peng, C. Y.: Nanayakkara. A.: Gonzalez. C.: Challacombe, M: Gill. P. M. W: Johnson. B.; Chen, W.: Wong, M. W: Andres. I. L.: Head-Gordon. M.: Replogle. E. S.: Pople. I. A. Gaussian 98. Revision A.6. Gaussian1. Inc.: Pittsburgh. PA. 1998.

8. (a) Lary. A.: Redtern. P. C.: Raghaqachari. K.: Pople. J. A. J. Chent. Phos 1998, 109, 42. (b) Curtiss. L. A.; Raghavachari, K.: Redfern. P. C.; Pople, J. A. J. Chem. Phys. 1997, 106. 1063

9. Curtiss, L. A.: Raghavachari, K.: Pople. J. A. J. Chem. Phys. 1993. 98. 1293.

10. Curtiss. L. A.: Raghavachari. K.: Redfem. P. C.: Rassolov. V: Pople. T. A. J. Chent. Phos 1998. 109. 7764

11. Curtiss, L. A.: Redfern, P. C. Raghavachari. K: Rassolov, V: Pople. J. A. J. Chem. Phys. 1999. 110,4703.

12. Eq. (2) is the reverse reaction of eq. (1) for $\mathrm{R}-\mathrm{H}$. In the case of proton. this reaction energy is usually defined as heterolytic bond dissociation energy not as hydride ion affinity of proton.

13. The experimental $\Delta \mathrm{H}_{\mathrm{I}}$ value is obtained by using the experimental $\Delta \mathrm{H}_{\mathrm{f}}\left(\mathrm{H}^{+}\right)=365.7$ and $\Delta \mathrm{H}_{\mathrm{f}}\left(\mathrm{H}^{-}\right)=34.7 \mathrm{kcal} \mathrm{mol}{ }^{-1}$ : Rosenstock. $\mathrm{H}$. M.; Drasl. K.: Steiner, B. W.: Herron. J. T. J. Phys. Chem. Ref. Data. Supp. 1977,6.

14. Lykke. K. R.: Murray. K. K.: Lineberger. W. C. Plys. Rev A 1991. +3.6104 .

15. QCISD(T) 6-311++G(3df.2p) calculation of t-butane requires $3 \mathrm{~Gb}$ of main memory and about 40 Gbyte of disk storage. 